Bayero Journal of Pure and Applied Sciences, 7(2): 1 - 7

Received: April 2014

Accepted: November 2014

ISSN $2006-6996$

\title{
DEVELOPMENT OF A PAR-BOILED RICE SOLAR DRYER
}

\author{
*Abubakar, M.S. and Isiyaku, D. \\ Department of Agricultural Engineering, Bayero University, PMB 3011, Kano, Nigeria \\ *Correspondence author: amshuaibu.age@buk.edu.ng
}

\begin{abstract}
Energy is required in various forms to do useful work and necessary for the continual improvement in the standard of any society. This study presents the development of a par-boiled batch type rice solar dryer using an indirect mode natural convection solar energy. The dryer was designed and constructed to provide easier, faster and more efficient par-boiled rice drying method. The dryer has the capacity of drying $30 \mathrm{~kg}$ of the par boiled rice per batch. The major design features of the dryer include a convenient drying process, uniformity in drying product, protect the quality of the drying products, minimal heat loss from the drying chamber. The developed dryer have generated higher air temperature and consequent/y lowered the relative humidity which are both conducive to improve the drying rate and lower the moisture content of the dried products. Preliminary performance evaluation of the dryer was also carried out. It was concluded that the dryer could be used for drying par-boiled dry in a batch.
\end{abstract}

Keywords: Par-boiled, batch, solar dryer, natural convection, rice

\section{INTRODUCTION}

Energy is required in various forms to do useful work and also necessary for the continual improvement in the standard of any society. Energy sources therefore have to be explored and developed to enhance industrial progress, national security and financial instability made a great effect on quality of human life since his existence (Fadele et al., 1985). With the recognition of the fact that domestic inflation and related economic factors, adjustment in the life style and national security are highly dependent on the available of energy supplies, pursuit of new, alternative sources of energy and conservation of energy is a task for research and development (Madhlopa et al., 2002). It is therefore required to discover new sources of energy, obtain sufficient supply of energy for future use and make it available wherever it is needed. Solar energy is highly abundant and can be utilized economically to supply the energy needed by the world. The source of energy is direct from the sun whose quantities falling on the global 500 times greater than that the total energy released (Fadele et al., 1985). This source of energy exist only during day time dependence on clouds whereas on cloudless weather, it does not usually exceed $70 \%$ (Arinze, 1986). The sun is among the stars that exist in the sky and it originated between eight and ten billions years ago and its present rate of energy output is approximately $3.8 \times 10^{22} \mathrm{~kW}$ caused by the conversion of mass into the energy at the rate of 4.7 million tons per second (Arinze, 1986). It is expected to emit radiant energy at the rate of another four billions years, therefore it is the only continuously renewable source of energy that can be used for any practical purpose. Most importantly, it is the only totally non-polluting and inexhaustible energy source, especially in terms of drying process. Solar energy technology and research is fast growing in the field of solar crop drying techniques, which provide heating at economically competitive costs and without environmental pollution and safety consideration. Nigeria is an agrarian country with over $75 \%$ of her population engaged in agriculture, but record have shown that $50-60 \%$ of the farmers encountered grains lost due to poor drying method, which obviously needs an urgent solution to arrest this great loss of agricultural products (Fadele et al., 1985). Although, even before the energy crisis of the seventies that caused considerable focus on the potential of application of solar energy and global economics recession, effort have already been made and still being made toward harnessing ever free and abundant energy source (i.e. solar energy for the preservation of agricultural products), this prospect and utilization depends on the duration of effective sunshine per day. Sun drying is still the most common method used to preserve agricultural products in most tropical and subtropical countries. However, being unprotected from rain, wind-borne dirt and dust, infestation by insects, rodents and other animals. Therefore, the utilization of solar energy for crop preservation in this country is a feasible idea, the system must be devised in which drying takes place in a compartment out of reach of animals and insects. Some of the problems associated with open-air sun drying can be solved through the use of a solar dryer which is comprises of collector, a drying chamber and sometimes a chimney (Madhlopa et al., 2002). The study is aimed at the design of a natural convection solar dryer and construction of a prototype of the dryer for drying par-boiled rice.

\section{MATERIALS AND METHODS \\ Design Considerations}

The establishment of design conditions is necessary for effective design of the proposed solar dryer. The design considerations were established as follows: 
1. Quantity of par-boiled rice to be dried at a given time; the initial and final moisture contents of the par-boiled rice. These are necessary for determination of the amount of moisture to be removed.

2. Sunshine hour's for selection of drying time.

3. Ambient air temperature, air relative humidity and permissible temperature of the drying air.

4. Daily or average monthly solar radiation for determining of energy received by the dryer per day.

5. Heat transfer efficiency.

6. Low cost: it is important that the dryer should have low capital and operating costs because of the seasonal nature of usage and low financial capability of the end users. This is necessary so that the investment may be recovered in a reasonable time period.

7. Use of locally available materials and technologies for construction and maintenance. This is necessary because of the low technical knowledge of the end users.

8. Medium capacity to satisfy the need of the farmers during the peak period of processing.

9. Energy efficiency.

10. Simplicity and durability: the dryer should be simple in design for ease of construction, usage and maintenance. It should also be durable to withstand adverse weather condition and rough handling by the operator (Arinze, 1983).

\section{Design Parameters and Assumptions}

The criterion is to develop a par-boiled batch type rice solar dryer. The development is based on some fundamental design parameters and assumptions which have been used to calculate some basic operational features of the dryer.

Quantity of par-boiled rice to be dried per batch $\left(\mathrm{W}_{1}\right)$ $=30 \mathrm{~kg}$

Initial moisture content of the wet par-boiled rice $\left(\mathrm{M}_{\mathrm{i}}\right)$

$=36 \%$ (wb) (Ampratwum, 1998)

Final moisture content of the dried par-boiled rice $\left(\mathrm{M}_{\mathrm{f}}\right)$ $=14 \%(\mathrm{wb})$ (Ampratwum, 1998)

Latent heat of vaporization of water from rice $(\mathrm{H})=$ $1.669 \mathrm{~mJ}$ (Amer et al., 2010)

Mean ambient temperature $\left(\mathrm{T}_{\mathrm{ab}}\right)=28{ }^{\circ} \mathrm{C}$ (Jindal and Gunasekaran, 1982)

Maximum Allowable drying air temperature $\left(T_{\max }\right)=$ $55^{\circ} \mathrm{C}$ (Jindal and Gunasekaran, 1982)

Drying air temperature $\left(T_{d}\right)=45^{\circ} \mathrm{C}$

Mean ambient relative humidity $\left(\square_{\mathrm{ab}}\right)=31.1 \%$ (Berinyuy, 2004)

Mean ambient air velocity $\left(\mathrm{V}_{\mathrm{ab}}\right)=5 \mathrm{~m} / \mathrm{s}$ (Jindal and Gunasekaran, 1982)

Monthly average daily horizontal radiation $(R)=27.55$ $\mathrm{mJ} / \mathrm{m}^{2}$ (Berinyuy, 2004)

Mean daily global radiation $\left(\mathrm{I}_{\mathrm{H}}\right)=1367 \mathrm{~W} / \mathrm{m}^{2}$ (Berinyuy, 2004)

Assumed collector efficiency $\left(\square_{c}\right)=40 \%$ (Berinyuy, 2004)

Thickness of the solar collector $=0.3 \mathrm{~m}$ (Amer et al., 2010)

Specific heat of the rice $\left(C \mathrm{p}_{\mathrm{m}}\right)=4.595 \mathrm{~kJ} / \mathrm{kg}$ (Amer et al., 2010)

Heat of vaporization at $55^{\circ} \mathrm{C}\left(\mathrm{I}_{\mathrm{V}}\right)=2381.65 \mathrm{~kJ} / \mathrm{kg}$ (Jindal and Gunasekaran, 1982)

Heat removal factor $\left(F_{R}\right)=0.8$ (Duffie and Beckman, 1980)

Effective transmittance absorption property $=0.8$

(Jindal and Gunasekaran, 1982)

Bulk density of paddy rice $=600 \mathrm{~kg} / \mathrm{m}^{3}$

Width of solar collector $=0.1 .7 \mathrm{~m}$ (Berinyuy, 2004)

Thickness of rice on drying chamber $=0.02 \mathrm{~m}$ (Basunia and Abe, 2001).

\section{Design Calculation}

\section{Determination of the amount of moisture to be remove from the par-boiled rice}

The amount of moisture to be removed can be calculated using the relationship below as reported by Afriyie et al.,(2011);

$$
\mathrm{M}_{\mathrm{w}}=\frac{\mathrm{W}_{1}\left(\mathrm{Mi}-\mathrm{M}_{\mathrm{F}}\right)}{100-\mathrm{M}_{\mathrm{F}}}
$$

Where, $\mathrm{M}_{\mathrm{w}}=$ Weight of moisture to be dried $(\mathrm{kg})$

$\mathrm{W}_{1}=$ Weight of par-boiled rice to be dried per batch $(30 \mathrm{~kg})$

$M_{i}=$ Initial moisture content of par-boiled rice $(36 \%)$

$M_{\mathrm{f}}=$ Final moisture content of par-boiled rice (14\%)

\section{Energy required to remove the moisture content}

The energy require to evaporate the available moisture content in the using Afriyie et al.,(2011) relationship as follows;

$E=W_{1} C p_{m}\left(T_{2}-T_{1}\right)+I_{v} M w$

Where,

$\mathrm{E}=$ Collector useful energy gain, $\mathrm{kJ}$

$\mathrm{W}_{1}=$ Weight of material to be dried, $30 \mathrm{~kg}$

$\mathrm{Cp}_{\mathrm{m}}=$ Specific heat of material, $\mathrm{kJ} / \mathrm{kg}^{\circ} \mathrm{C}$

$\mathrm{T}_{2}=$ Temperature of drying air $=55^{\circ} \mathrm{C}$

$\mathrm{T}_{1}=$ Ambient air temperature $28^{\circ} \mathrm{C}$

$\mathrm{I}_{\mathrm{V}}=$ Heat of vaporization at $55^{\circ} \mathrm{C}=2381.65 \mathrm{~kJ} / \mathrm{kg}$

$M_{w}=$ Weight of moisture to be removed $=7.7 \mathrm{~kg}$

Assumed the following 
$\mathrm{CP}_{\mathrm{m}}$ of rice $=4.595 \mathrm{~kJ} / \mathrm{kg}$ (Madhlopa et al., 2002)

$\mathrm{I}_{\mathrm{V}}$ at $55^{\circ} \mathrm{C}=2381.65 \mathrm{~kJ} / \mathrm{kg}$ (Berinyuy, 2004)

This is the energy required for four days at 8 hours sunshine

Therefore energy required per hour, $\mathrm{Q}_{\mathrm{R}}$

$$
\mathrm{Q}_{\mathrm{R}}=\frac{\mathrm{T}}{\mathrm{B}}
$$

\section{Area of the solar collector}

The collector area required to supply the useful energy for drying can be calculated for horizontal surface using Basunia and Abe (2001) relationship as follows;

$$
\begin{aligned}
& \mathrm{Q}_{\mathrm{R}}=\mathrm{A}_{\mathrm{c}} \mathrm{F}_{\mathrm{R}} \mathrm{h}_{\mathrm{e}} \mathrm{I}_{\mathrm{H}} \\
& \mathrm{A}_{\mathrm{c}}=\frac{\mathrm{QR}_{\mathrm{R}}}{F \mathrm{k} h \mathrm{el} / \mathrm{H}}
\end{aligned}
$$

Where $\mathrm{Q}_{\mathrm{R}}=$ Total useful energy, $\mathrm{kJ} / \mathrm{hr}$

$\mathrm{A}_{\mathrm{c}}=$ Solar collector area, $\mathrm{m}^{2}$

$\mathrm{F}_{\mathrm{R}}=$ Heat removal factor $=0.8$ for air cooled collector

$\mathrm{h}_{\mathrm{e}}=$ Effective transmittance-absorption product $=0.8$ for a single transparent covering and black painted surface

$\mathrm{I}_{\mathrm{H}}=$ Mean daily global radiation $=1367 \mathrm{~W} / \mathrm{m}^{2}$

Also the length of the solar collector was obtained from the equation below as reported by Basunia and Abe (2001);

Length of solar collector $=\frac{\text { Area of collector }}{\text { width of collector }}$

Tilt angle of solar collector

This is the slope at which the solar collector has to be tilt and was chosen to be as reported by Basunia and Abe (2001);

$\square=(\mathrm{L}+5)^{\circ} \mathrm{N}$

Where;

$L=$ Latitude of the place the dryer is to be used

$5=$ Constant at any place where the latitude is greater than $8.5^{\circ} \mathrm{N}$ and Kano is at $12^{\circ} \mathrm{N}$

\section{Determination of the thickness of the bottom insulator $(X)$}

Heat loss can be minimized by the choice of insulator, hence its ability to prevent heat loss from the bottom and sides of the collector. Saw dust was used as the insulator which is cheap and readily available. The thermal conductivity of saw dust, $\mathrm{K}=0.0649 \mathrm{~m}^{20} \mathrm{C} / \mathrm{w}$, resistance to heat flow by the insulator (saw dust), $\mathrm{R}$ $=0.1417 \mathrm{~m}^{20} \mathrm{C} / \mathrm{w}$ (Anderson, 1946).

From the relationship;

$$
\begin{aligned}
& \mathrm{R}=\frac{\mathrm{X}}{\mathrm{K}} \\
& \mathrm{X}=\mathrm{RK} \\
& \text { Where, } \mathrm{X}=\text { Insulator thermal thickness }
\end{aligned}
$$

\section{Determination of the thickness of the absorber plate $(\delta)$}

Aluminum sheet was selected at the bottom of the solar collector because it is very good conductor of heat (Afriyie et al., 2011). The thickness of the absorber plate was calculated from Amer et al.,(2010) relationship.

$\mathrm{K} \delta=0.2$

$\delta=\frac{0.2}{K}$

Where $\mathrm{K}=$ thermal conductivity of Aluminum sheet, $210 \mathrm{~W} / \mathrm{m}^{2}$

$\delta=$ thickness of absorber

\section{Design of Drying Chamber (Cabinet)}

To prevent over heating of the par-boiled rice and consequent loss of the nutrient, the temperature of the air entering the cabinet should not exceed the maximum temperature for safe drying of the rice.

\section{Determination of the surface area of the drying cabinet}

Given that, the bulk density of the paddy rice was $600 \mathrm{~kg} / \mathrm{m}^{3}$, the bulk volume occupied by $30 \mathrm{~kg}$ of the parboiled rice was computed from equation below as reported by Afriyie et al.,(2011); $\mathrm{V}=\frac{\text { Mass of the par-boiled rice }}{\text { Bulk densiry }}$ 
Hence, the quantity that determines the cross area of the cabinet was determined by dividing the bulk volume of the rice by the recommended rice thickness on the drying chamber $0.02 \mathrm{~m}$ (Basunia and Abe, 2001);

Area of cabinet $=\frac{0.05}{0.02}=2.5 \mathrm{~m}^{2}$

Determination of the drying period (day) of the par-boiled rice

To calculate the period it takes to dry $30 \mathrm{~kg}$ of the par-boiled rice per day. Assuming Kano State have an average sunshine of 8 hours in a day (Fadele et al., 1985).

From conservation of energy,

$\mathrm{M}_{\mathrm{w}} \mathrm{H}=\mathrm{nA}_{\mathrm{c}} \mathrm{I} \square_{\mathrm{c}}$

$\mathrm{n}=\frac{M w H}{A c \ln E}$

Where, $\mathrm{M}_{\mathrm{w}}=$ total energy required to evaporated $7.7 \mathrm{~kg}$ of moisture content from the par-boiled rice.

$\mathrm{H}=$ Latent heat of vaporization of water, $2.85 \mathrm{~mJ} / \mathrm{kg}$

$\mathrm{n}=$ Number of drying period (days)

$\mathrm{A}_{\mathrm{c}}=$ Area of collector, $\mathrm{m}^{2}$

$\mathrm{I}=$ Solar constant, $1367 \mathrm{~W} / \mathrm{m}^{2}$

$\square_{\mathrm{c}}=$ Collector efficiency $40 \%$

$\mathrm{n}=\frac{7.7 \times 2.85 \times 10^{6}}{3.15 \times 1367 \times 0.4}=44543 \mathrm{~s}$

\section{Dimension of the drying cabinet}

To obtain the dimension of the drying cabinet the width of the drying cabinet was the same with the width of the solar collector. Therefore, the length $L$ of the drying cabinet will be,

$L=\frac{\text { Area of drying carbinet }}{\text { width of the drying cabinet }}$

\section{Height of the drying cabinet}

The clearance provided for solar collector was $0.3 \mathrm{~m}$ (Fadele et al., 1985) and the clearance between the top most drying bed and the chimney was assumed to be $0.6 \mathrm{~m}$ (Ampratwum, 1998).

\section{Height of supporting legs}

It was gotten earlier that the tilt angle of the collector was $17^{\circ}$ due South and the length of the collector was obtained to be $1.7 \mathrm{~m}$ (Figure 1).

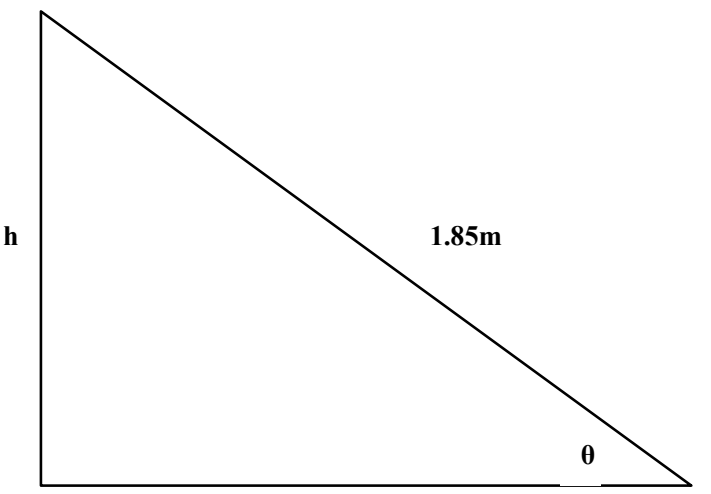

Figure 1: Triangle for determining height of the supporting legs of the dryer

Where, $\mathrm{h}$ is the height of the collector from the ground level when it is inclined at angle $17^{\circ}$ which is also equal to the height of the supporting legs.

Thus; $\operatorname{Sin} 17=h / 1.85$

Basunia and Abe (2001) recommended that the incline end of the collector should not be more than $0.1 \mathrm{~m}$ so the height of the supporting legs are taken to be $0.1 \mathrm{~m}$. 


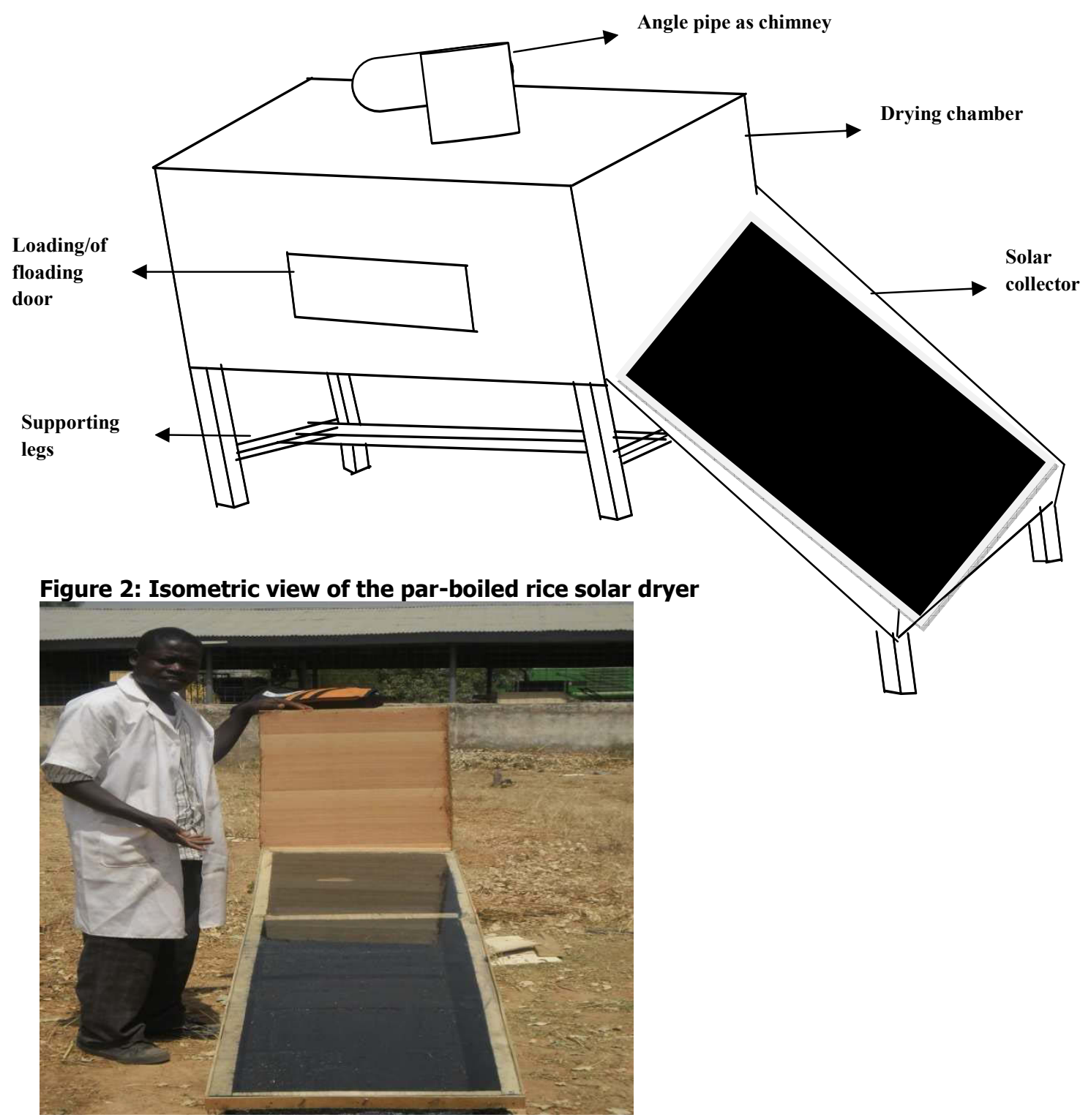

Plate 1: A batch type par-boiled rice solar dryer

Figure 2 and Plate 1 show the isometric and pictorial views of the developed batch type par-boiled rice solar dryer, respectively.

\section{RESULTS AND DISCUSSION}

Table 1 presents the summary of the design calculation of the drying cabinet and solar collector of par-boiled rice solar dryer.

\section{Table 1: Calculated values of the par-boiled rice dryer design parameters}

\begin{tabular}{llc}
\hline \multicolumn{1}{c}{ Determined design parameters } & Calculated values \\
\hline S/No. & \multicolumn{1}{c}{ Tilt angle of the solar collector, $\square(\square \mathrm{N})$} & 17 \\
1. & Area of the solar collector, $\mathrm{A}_{\mathrm{c}}\left(\mathrm{m}^{2}\right)$ & 3.15 \\
2. & Weight of moisture to be removed from the rice, $\mathrm{M}_{\mathrm{w}}(\mathrm{kg})$ & 7.7 \\
3. & Thickness of the bottom insulator, $\mathrm{X}(\mathrm{mm})$ & 9.2 \\
4. & Thickness of the absorber plate, $0(\mathrm{~mm})$ & 1 \\
5. & 1.5 \\
6. & Drying period of a batch of $30 \mathrm{~kg}$ of the rice, $\mathrm{n}$ (days) & 2757.6 \\
7. & Total drying energy per hour, $\mathrm{Q}_{\mathrm{R}}(\mathrm{kJ} / \mathrm{hr})$ & 0.05 \\
8. & Bulk volume of the rice, $\mathrm{V}\left(\mathrm{m}^{3}\right)$ & 0.64 \\
9. & Depth of the drying bed $(\mathrm{m})$ & 2.5 \\
10. & Area of the drying cabinet $\left(\mathrm{m}^{2}\right)$ & 1.4 \\
11. & Height of the drying cabinet from the ground level $(\mathrm{m})$ & 0.5 \\
12. & Height of supporting legs $(\mathrm{m})$ & \\
\hline
\end{tabular}


The solar collector was constructed in such a way that it can be detached from the drying cabinet for easy keeping while it is not in use and one can fix it back when its use arise by slotting it to the hollow of the drying cabinet (Plate 2). A maximum possible length of the collector and a reasonable space between the absorber plate and the cover glass was chosen to ensure effective heating of the drying air. The transparent cover placed above the absorber plate serving as a transmission medium of radiation to reduced heat lost from the absorber plate to the surrounding (Fadele et al., 1985) was a single layer of transparent glass of $5 \mathrm{~mm}$ in order to have an efficient transmissivity because a double layer set distance apart which will cause reflection of the incoming sunlight.

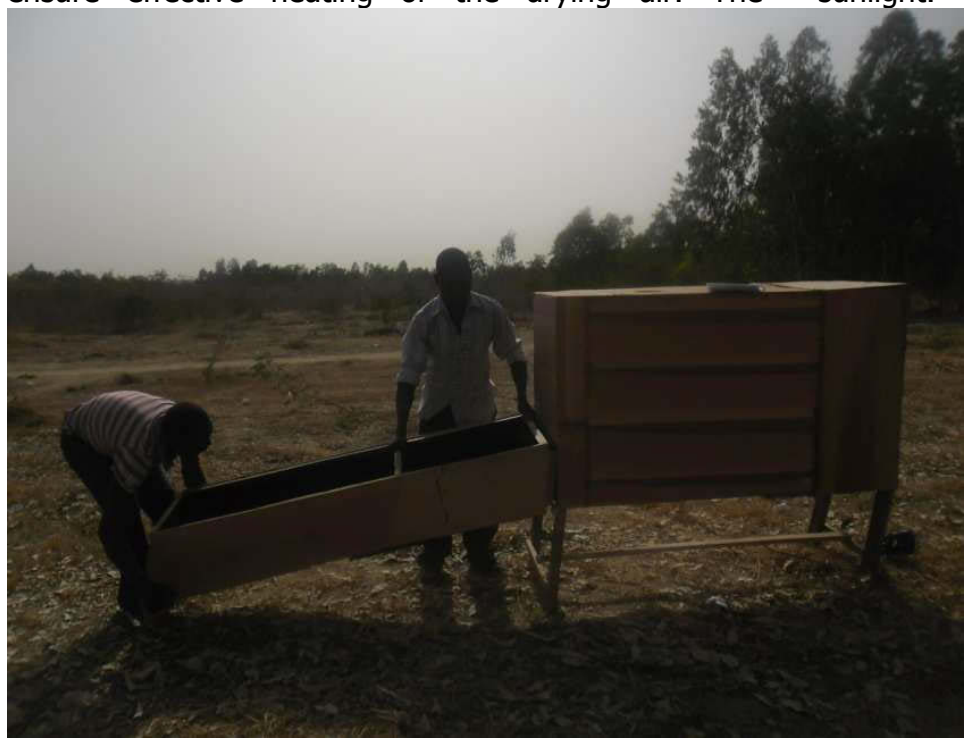

\section{Plate 2: Detachable solar collector with the drying cabinet}

The par-boiled rice batch type solar dryer designed was carried out using natural convection which is suitable for areas where there is less frequent or no electric supply, because the dryer does not require electricity to be operated. Finally the dryer performance was pre-evaluated (Plate 3).

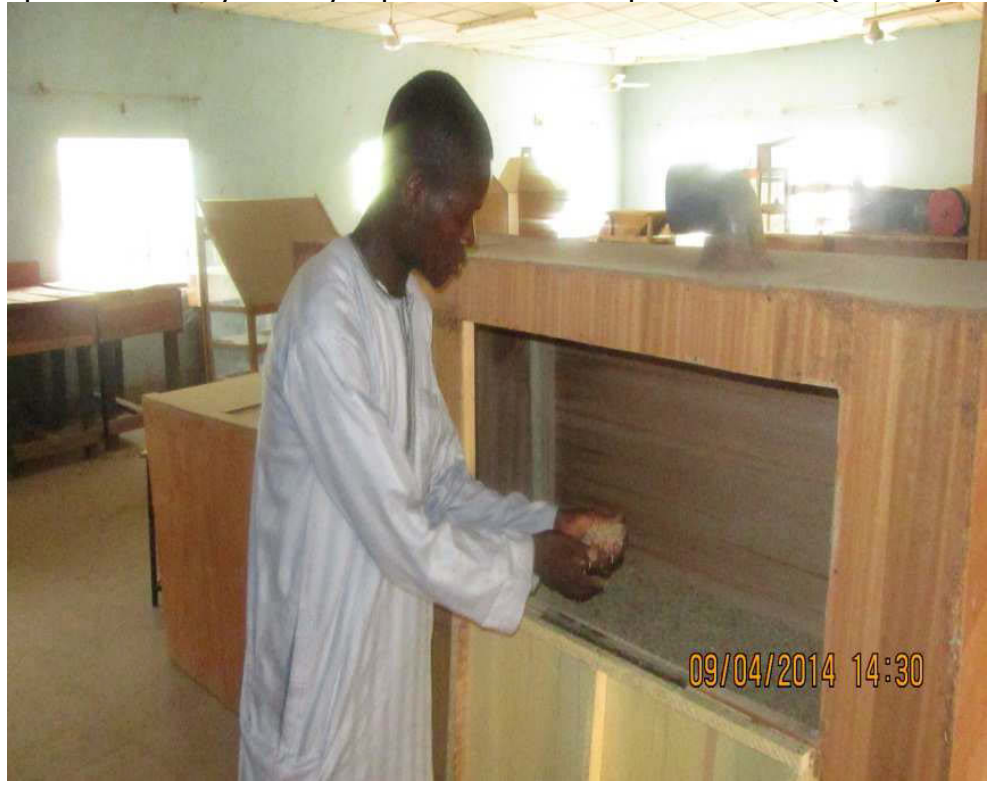

Plate 3: Sample of dried par-boiled rice by the solar dryer

The dryer was evaluated on a two hourly basis using the solar dryer can be used to dry par-boiled rice method described by Duffie and Beckman (1980). The evaluation was carried out in the month of March 2013 with sample of par-boiled rice having initial moisture content of $20 \%$ (wb). The ambient temperature and the relative humidity in the evaluation area were found to be $40.2^{\circ} \mathrm{C}$ and $11.2 \%$ respectively. After 1.5 days (12 hours of sunshine that is; 8 hours of sunshine per day plus 4 hours which is half a day) of drying the moisture content was found to be $14.2 \%(w b)$. Thus, it could be established that without the effect of wind, insects, rain and some impurities when compared with open (under the sun) drying method. The evaluation also shows that the higher the temperature generated in the solar collector the more the moisture content of the parboiled rice was removed. The Table 2 below shows the various temperatures generated at the solar collector and the moisture content (wb) of the parboiled rice measured after every 2 hours interval of sunshine. 
Table 2: Values of temperature generated at the solar collector and moisture content of the parboiled rice at the drying cabinet of the dryer

\begin{tabular}{cccc}
\hline S/No. & $\begin{array}{c}\text { Time Interval } \\
\text { (hrs) }\end{array}$ & $\begin{array}{c}\text { Temperature Generated at the Solar } \\
\text { Collector }\left({ }^{\circ} \mathbf{C}\right)\end{array}$ & $\begin{array}{c}\text { Moisture Content (\% ) } \\
\text { (wb) }\end{array}$ \\
\hline 1 & $12: 30 \mathrm{pm}$ & 53.3 & 20 \\
2 & $02: 30 \mathrm{pm}$ & 54.8 & 18.2 \\
3 & $04: 30 \mathrm{pm}$ & 47.0 & 17.4 \\
4 & $06: 30 \mathrm{pm}$ & 45.2 & 16.9 \\
5 & $09: 30 \mathrm{am}$ & 42.7 & 16.0 \\
6 & $11: 30 \mathrm{am}$ & 51.0 & 15.4 \\
7 & $01: 30 \mathrm{pm}$ & 55.5 & 14.2 \\
\hline
\end{tabular}

\section{Conclusion}

The following conclusions were drawn from the study;

1. A natural convection batch type solar energy dryer for drying par-boiled rice was developed.

2. The preliminary performance evaluation of the dryer was carried out.

\section{Recommendations}

The following recommendations were made;

1. The dryer should be tested for other similar grains.

2. The area of the drying cabinet should be design in such that the thickness of the rice

\section{REFERENCES}

Afriyie, J. K., Rajakaruna, H., Nazha, M. A. A., and Forson, F. K. (2011). Simulation and optimization of the ventilation in a chimneydependent solar crop dryer. Solar Energy, 85, 1560-1573.

Amer, B. M. A., Hossain, M. A., and Gottschalk, K. (2010). Design and performance evaluation of a new hybrid solar dryer for banana. Energy Conversion and Management, 51, 813-820.

Ampratwum, D. B. (1998). Design of solar dryer for dates. Agricultural Mechanization in Asian, Africa, and Latin America, 29(3), 59-62.

Anderson, R. B. (1946). Modification of the BET equation. Journal of the American Chemical Society, 68, 656-691.

Arinze, E. A. (1983). Design and performance evaluation of a commercial size of a natural convectional solar dryer. Nigerian Journals of Solar Energy, 4, 106-120.

Arinze, E. A. (1986). Solar energy utilization in crop drying. Nigerian Journals of Solar Dryers, 5, 10-15. on the drying bed should be minimize in order to have better air flow in the drying cabinet.

3. This design was based on natural convection, but the drying period (day) could further be reduced when an electric motor driven fan could be incorporated at the air inlet of the drying cabinet to increase its flow rate.

4. Also the design was based on a single transparent cover, the amount of solar radiation trapped may be further increased by increasing the number of transparent cover up to 2 or 3 number.

Basunia, M. A., and Abe, T. (2001). Design and construction of a simple three-shelf solar rough rice dryer. Agricultural Mechanization in Asian, Africa, and Latin America, 32(3), 54-58.

Berinyuy, J. E. (2004). A solar tunnel dryer for natural convection drying of vegetables and other commodities in Cameroon. Agricultural Mechanization in Asian, Africa, and Latin America, 35(2), 31-35.

Duffie, J. A., and Beckman, W. A. (Eds.). (1980). Solar engineering of thermal processes. New York: John Wiley and Sons.

Fadele, A., Alabe, S. O., and Akinsete, V. A. (1985). A solar grain dryer for rural areas of Nigeria. Nigerian Journal of solar energy, 3, 122-130.

Jindal, V. K., and Gunasekaran, S. (1982). Estimating air flow and drying rate due to natural convection in solar rice dryers. Renewable energy review, 4(2), 1-9.

Madhlopa, A., Jones, S. A., and Kalenga Saka, J. D. (2002). A solar air heater with Composite absorber systems for food dehydration. Renewable energy review, 27, 27-37. 